\section{Effects of Growth Substrate and Container Size on Cutting Production from Mojave Sage Stock Plants}

\author{
Sean J. Markovic ${ }^{1}$, Shana G. Brown ${ }^{1}$, and James E. Klett ${ }^{1}$
}

AdDITIONAL INDEX wORDs. herbaceous perennial, Salvia pachyphylla, soilless media, vegetative propagation

SUMMARY. Stock plant productivity is an important concern for growers of mojave sage (Salvia pachyphylla) because this species produces more woody growth as the plant ages. The objective of the study was to determine the best growth substrate and container size combination to maximize stock plant productivity. A secondary objective was to determine whether the stock plant treatments influenced the rooting of vegetative cuttings. Three different container sizes $(3,12$, and $15.5 \mathrm{qt})$ and four soilless substrates composed primarily of bark, peat, and perlite (substrate 1); bark, peat, and vermiculite (substrate 2); bark, peat, and coarse perlite (substrate 3 ); and peat (substrate 4) were used. The stock plant experiment was conducted using 12 treatment combinations, and a subset of those stock plants was selected randomly for the rooting study that immediately followed the stock plant experiment. Stock plants responded to substrate treatments differently. The most successful stock plants, which produced more cuttings per plant and per square foot, as well as larger cuttings, were those grown in substrate 3 . Regardless of substrate, the highest number of cuttings per square foot was obtained from stock plants grown in 3 -qt containers, indicating that the smaller containers allow for the most efficient use of space when growing mojave sage stock plants for 4 to 6 months. The rooting of vegetative cuttings was successful $(88 \%$ to $100 \%$ of cuttings rooted after 4 weeks under mist) for all treatment combinations.

M ojave sage (Salvia pachyphylla) has become an important landscape herbaceous perennial in the western United States. It is grown for its attractive silver foliage and soft purple flowers. The preferred propagation method for mojave sage is by vegetative cuttings. Stock plants grown in containers become more productive as the plants mature until plant growth declines, resulting from limited root space or shoot crowding. The duration of increased productivity can also be influenced by management practices (Adam, 2005).

Two cultural factors that affect growth of stock plants are container

Received for publication 27 Mar. 2020. Accepted for publication 20 May 2020.

Published online 12 June 2020.

${ }^{1}$ Department of Horticulture and Landscape Architecture, Colorado State University, 301 University Avenue, Fort Collins, CO 80523-1173

Mention of a trademark, proprietary product, or vendor does not constitute a guarantee or warranty of the product by Colorado State University and does not imply its approval to the exclusion of other products or vendors that also may be suitable.

J.E.K. is the corresponding author. E-mail: jim.klett@ colostate.edu.

This is an open access article distributed under the $\mathrm{CC}$ BY-NC-ND license (https://creativecommons.org/ licenses/by-nc-nd/4.0/).

https://doi.org/10.21273/HORTTECH04620-20 size and substrate. Although perennial growers often use the same substrate for the majority of their stock plants, the suitability of the substrate varies according to species (Ingram et al., 1993).

Container size can affect the morphological and physiological properties of plants, and effects are more evident in smaller containers (NeSmith and Duval, 1998). Growth of belowground organs (such as roots) is tied to the growth of the aboveground tissues because they rely on each other for different substances (Tonutti and Giulivo, 1990). Roots rely on the shoots to provide carbohydrates and hormones such as auxins and gibberellins, but the shoots also rely on the roots for water and nutrients (Tonutti and Giulivo, 1990). The environment within the growth substrate may be more important than the environmental conditions of the aerial parts of the plant because extreme temperature fluctuations of the root zone and more accelerated water depletion can occur under rootrestricted conditions (Poorter et al., 2012).

Perennial growers reported low cutting numbers and low rooting percentage with mojave sage. To address these issues, a research project was designed to examine the effects of stock plant container size and growth substrate on the number and quality of vegetative cuttings produced as well as the rooting of cuttings.

\section{Materials and methods}

A stock plant experiment was conducted in Fort Collins, CO, at the Colorado State University Horticulture Center in a double-wall polycarbonate greenhouse. The stock plant experiment used 12 treatment combinations of substrate and container size to determine how these factors affect the number and quality of cuttings that can be produced each month.

Rooted plugs were obtained from a local grower (Gulley Greenhouse, Fort Collins, CO) in 72-cell plant plug trays, transplanted into green plastic 4 -inch square pots (48 inch $^{3}$ ) on 7 Aug. 2017. During this establishment period, plants were grown in four commercial substrates: substrate 1 ( $\mathrm{Sl}$ ), consisting of bark, coarse peatmoss, and perlite (BM-7; Berger, Saint-Modeste, QC, Canada); substrate 2 (S2), consisting of sphagnum peatmoss, vermiculite, and bark (Metro Mix 360; Sun Gro Horticulture, Agawam, MA); substrate 3 (S3) consisting of sphagnum peatmoss, perlite, bark, and coir (Metro

\begin{tabular}{llll}
\hline $\begin{array}{l}\text { Units } \\
\begin{array}{l}\text { To convert U.S. to SI, } \\
\text { multiply by }\end{array}\end{array}$ & U.S. unit & SI unit & $\begin{array}{l}\text { To convert SI to U.S., } \\
\text { multiply by }\end{array}$ \\
\hline 0.0929 & $\mathrm{ft}^{2}$ & $\mathrm{~m}^{2}$ & 10.7639 \\
3.7854 & gal & $\mathrm{L}$ & 0.2642 \\
2.54 & inch $(\mathrm{es})$ & $\mathrm{cm}$ & 0.3937 \\
16.3871 & inch & $\mathrm{cm}^{3}$ & 0.0610 \\
1 & $\mathrm{meq} / 100 \mathrm{~g}$ & $\mathrm{cmol}^{3} \cdot \mathrm{kg}^{-1}$ & 1 \\
1 & $\mathrm{mmho} / \mathrm{cm}$ & $\mathrm{mS} \cdot \mathrm{cm}^{-1}$ & 1 \\
28.3495 & $\mathrm{oz}$ & $\mathrm{g}$ & 0.0353 \\
1 & $\mathrm{ppm}$ & $\mathrm{mg} \cdot \mathrm{L}^{-1}$ & 1 \\
0.9464 & $\mathrm{qt}$ & $\mathrm{L}$ & 1.0567 \\
$\left({ }^{\circ} \mathrm{F}-32\right) \div 1.8$ & ${ }^{\circ} \mathrm{F}$ & ${ }^{\circ} \mathrm{C}$ & $\left({ }^{\circ} \mathrm{C} \times 1.8\right)+32$ \\
& & &
\end{tabular}


Mix 820, Sun Gro Horticulture); and substrate 4 (S4), composed of $70 \%$ blonde peatmoss and 30\% wood fiber (Pindstrup, Ryomgaard, Denmark) (Table 1). Exact scientific formulas for the four substrates are proprietary and not available for publication. After plants became established in the 4inch containers and roots held the substrate together (21 July 2017), plants were transplanted into round, black plastic 3-qt (\#1), 12-qt (\#3), or 15.5-qt (\#5) containers for the remainder of the study. After transplant, drip irrigation was installed using $0.5-\mathrm{gal} / \mathrm{h}$ drip emitters (Xeric Bug; Rainbird, Azusa, CA), and plants were fertilized with $20 \mathrm{~N}-4.4 \mathrm{P}-16.6 \mathrm{~K}$ fertilizer (Grow More, Gardena, CA) at 200 ppm nitrogen. Fertilizer was supplied using a liquid injector (model D14MZ2/14 GPM; Dosatron, Clearwater, FL) that provided nutrients with every irrigation, occurring twice weekly for $\mathbf{3 0}$ min. Supplemental water without fertilizer was applied between irrigation times only when it was determined to be necessary to maintain plant health. Small platforms were placed underneath \#1 and \#3 containers to elevate them to the same height as the \#5 containers to eliminate shading.

During the experiment, cuttings were taken 7 Nov. 2017, 7 Dec. 2017, and 4 Jan. 2018. The protocol used to determine suitable cuttings was developed by combining a visual guide from Gulley Greenhouse (Fig. 1) and descriptions of ideal cuttings from perennial growers of this variety who were interviewed. Based on information from multiple growers, the typical and most successful mojave sage cutting is $\approx 0.25$ inch wide at the base with 0.5 to 1 -inch stems with no dense, hardened basal tissue.
The experiment was conducted from Nov. 2017 to Jan. 2018. Greenhouse temperatures were maintained between 65 and $73^{\circ} \mathrm{F}$ (day) and 61 to $73^{\circ} \mathrm{F}$ (night) using an aspirator (model M4821; Wadsworth Control Systems, Arvada, CO). Shade cloths providing $\mathbf{5 0 \%}$ shade were set to close automatically only when needed for cooling. Supplemental lighting was provided by light emitting diode (LED) fixtures (Green Power LED Toplighting Module DR/W MB 200-400V; Philips, Amsterdam, The Netherlands). Supplemental lighting fluctuated with the natural daylength and provided $\approx 90 \%$ red and $10 \%$ blue light, and ran daily from sunrise to sunset $(9.5-11.5 \mathrm{~h})$.

Using a $3 \times 4$ factorial design, these experiments had two factors: four substrates (S1, S2, S3, and S4) and container size with three levels (\#1, \#3, and \#5). We grew 10 stock plants in each of the 12 treatment combinations, resulting in 120 total experimental units. Response variables for the stock plant experiment included average number of cuttings per plant, average number of cuttings per square foot, and average fresh weight per cutting. Average fresh weight per cutting is presented here because it better defines the quality of the cutting. All response variables were averaged over the 4-month period and were reduced to a single value per plant.

The number of cuttings per square foot was calculated by dividing the average number of cuttings per plant by the area occupied by each container size, allowing adequate space for growth. For this experiment, each plant was given 6 inches of space between containers to allow for air circulation and canopy expansion. Based on this measurement, \#l containers occupied $1.0 \mathrm{ft}^{2}$ whereas \#3 and \#5 containers occupied $2.25 \mathrm{ft}^{2}$. Analysis of cuttings per square foot was based on this spacing with the intention of discerning the value of using larger containers for commercial stock plant production.

The rooting of harvested cuttings was evaluated after the completion of each stock plant study and used a randomly selected subset of four stock plants from each treatment used for the substrate and container size study. The rooting study began in Feb. 2018 and ended in Mar. 2018. Cuttings were taken after 4 weeks of growth two times. Cuttings were dipped in a liquid rooting hormone (Dip 'N Grow, Clackamas, OR) at $500 \mathrm{ppm}$ indole butyric acid for $5 \mathrm{~s}$ before sticking in 72-cell plant plug trays (Preforma; Jiffy, Lorain, OH) that contained a peat and coir rooting substrate with proprietary binding agents. Trays of cuttings were placed on a greenhouse bench and watered with mist nozzles (0303421l-b pcs 25 coolpro c 4x7 5 head +ad20; Netafim, Fresno, CA) controlled by a six-zone misting timer (NOVA 1626ET; Phytotronics, Earth City, MO). The mist timer ran $24 \mathrm{~h} / \mathrm{d}$ and was applied in 10-s bursts every $15 \mathrm{~min}$ for the first week, every $30 \mathrm{~min}$ the second week, and every 60 min during the third and fourth weeks. The rooting substrate was kept at $75^{\circ} \mathrm{F}$ with bottom heat mats (Redi Heat model RHD2110, Phytotronics), and air temperature was maintained between 68 and $73{ }^{\circ} \mathrm{F}$.

Response variables for the rooting experiment included percentage of cuttings rooted and average number of visible roots of the 12 cuttings

Table 1. Substrate analysis before planting and postgrowth of greenhouse-grown mojave sage. Preplant (Pre) and postgrowth (Post) substrate analysis of substrate 1 [S1 (primarily bark, peat, and perlite)], substrate 2 [S2 (primarily bark, peat, and vermiculite)], substrate 3 [S3 (primarily bark, peat, and coarse perlite)], and substrate 4 [S4 (primarily peat)] for stock plant experiment (Aug. 2017 to Jan. 2018). Substrates were tested for total nitrogen, organic matter (OM), lime $\left(\mathrm{CaCO}_{3}\right), \mathrm{pH}$ using the paste method, ammonium to nitrate ratio $\left(\mathrm{NH}_{4}: \mathrm{NO}_{3}\right)$, carbon to nitrogen ratio $(\mathrm{C}: \mathrm{N})$, cation exchange capacity (CEC), and electrical conductivity (EC).

\begin{tabular}{|c|c|c|c|c|c|c|c|c|c|c|c|c|c|c|c|c|}
\hline \multirow[b]{2}{*}{ Substrate } & \multicolumn{2}{|c|}{$\begin{array}{c}\text { Total } \\
\text { nitrogen }(\%)\end{array}$} & \multicolumn{2}{|c|}{ OM (\%) } & \multicolumn{2}{|c|}{$\begin{array}{c}\mathrm{CaCO}_{3} \\
(\%)\end{array}$} & \multicolumn{2}{|c|}{$\mathrm{pH}$} & \multicolumn{2}{|c|}{$\begin{array}{l}\mathrm{NH}_{4}: \mathrm{NO}_{3} \\
\quad \text { (ratio) }\end{array}$} & \multicolumn{2}{|c|}{$\begin{array}{c}\mathrm{C}: \mathrm{N} \\
\text { (ratio) }\end{array}$} & \multicolumn{2}{|c|}{$\begin{array}{c}\text { CEC } \\
(\mathrm{meq} / 100 \mathrm{~g})^{\mathrm{z}}\end{array}$} & \multicolumn{2}{|c|}{$\begin{array}{c}\mathrm{EC} \\
(\mathrm{mmho} / \mathrm{cm})\end{array}$} \\
\hline & Pre & Post & Pre & Post & Pre & Post & Pre & Post & Pre & Post & Pre & Post & Pre & Post & Pre & Post \\
\hline Sl & 0.15 & 3.91 & 52.1 & 31.6 & 0.33 & 0.52 & 3.8 & 5.1 & 1.52 & 1.94 & 81.94 & 11.6 & 3.6 & 2 & 1.2 & 1.1 \\
\hline S2 & 0.1 & 3.77 & 32.4 & 17 & 0.26 & 0.6 & 3.8 & 4.7 & 1.41 & 1.9 & 55.23 & 9 & 4.3 & 2 & 1.7 & 1.4 \\
\hline S3 & 0.14 & 3.01 & 43.7 & 34.7 & 0.47 & 0.22 & 3.8 & 5.3 & 1.31 & 1.87 & 73.51 & 11.3 & 5.14 & 2 & 1.9 & 1.2 \\
\hline S4 & 0.3 & 2.78 & 59.7 & 17.7 & 0.47 & 0.31 & 4.7 & 5.8 & 1.22 & 1.89 & 41.25 & 18.8 & 11.4 & 3 & 2.4 & 0.9 \\
\hline
\end{tabular}

${ }^{\mathrm{z}} 1 \mathrm{meq} / 100 \mathrm{~g}=1 \mathrm{cmol} \cdot \mathrm{kg}^{-1}, 1 \mathrm{mmho} / \mathrm{cm}=1 \mathrm{mS} \cdot \mathrm{cm}^{-1}$. 
propagated for each treatment. The percentage of cuttings rooted was analyzed after averaging total rooted cuttings over the two rooting dates. Roots visible on the outside of the substrate cube were counted to determine the amount of root growth. The number of visible roots was analyzed by averaging over the two dates. No roots were counted above 50 because they became indistinguishable from one another. Twelve cuttings were taken for both dates from each substrate and container size combination for a total of 24 observations per treatment, for a total of 288 cuttings propagated.

Data were analyzed using $\mathrm{R}$ statistical software ( $\mathrm{R}$ Foundation for Statistical Computing, Vienna, Austria) and the lsmeans package (Fox and Weisberg, 2011) and run as a two-way analysis of variance, including substrate and container size as predictor variables. Least squares means were calculated for each response variable except percentage of cuttings rooted, which was analyzed with a chi-square test to determine the association between response and predictor variables. Tukey adjusted pairwise comparisons were considered, and significant differences were noted using $\alpha=0.05$ and $95 \%$ confidence intervals were constructed.

\section{Results and discussion}

CutTIngs Per PLANT. When data were averaged over substrate to examine the effects of container size, stock plants grown in \#l containers produced more cuttings than \#3 and \#5 containers (Fig. 2A). Pairwise comparisons of \#3 containers compared with \#5 container size did not differ, nor did the size $\times$ substrate interaction. The differences in mean response were very small, and the greatest number of cuttings was obtained from the smallest containers (Fig. 2A). Because this result contradicts previous container-size studies done on 'Kyoho' grape [Vitis labruscana (Xie et al., 2013)], tomato [Solanum lycopersicum (Bouzo and Favaro, 2015; Nishizawa and Saito, 1998)], scarlet sage [Salvia splendens (van Iersel, 1997)], and kiwifruit [Actinidia deliciosa (Tonutti and Giulivo, 1990)], among others, it is possible the duration of the experiment was not long enough to impact smaller container sizes with decreased growth resulting from limited growing space in the container. Although the data were statistically significant, the differences in response may not be critical for commercial producers in the long term.

CutTIngs PER SQUARE FOOT. The number of cuttings produced per square foot was greater in \#1 containers compared with \#3 and \#5 containers (Fig. 2B). The main effect of container size was significantly different, but the substrate and size $\times$ substrate interaction was not.

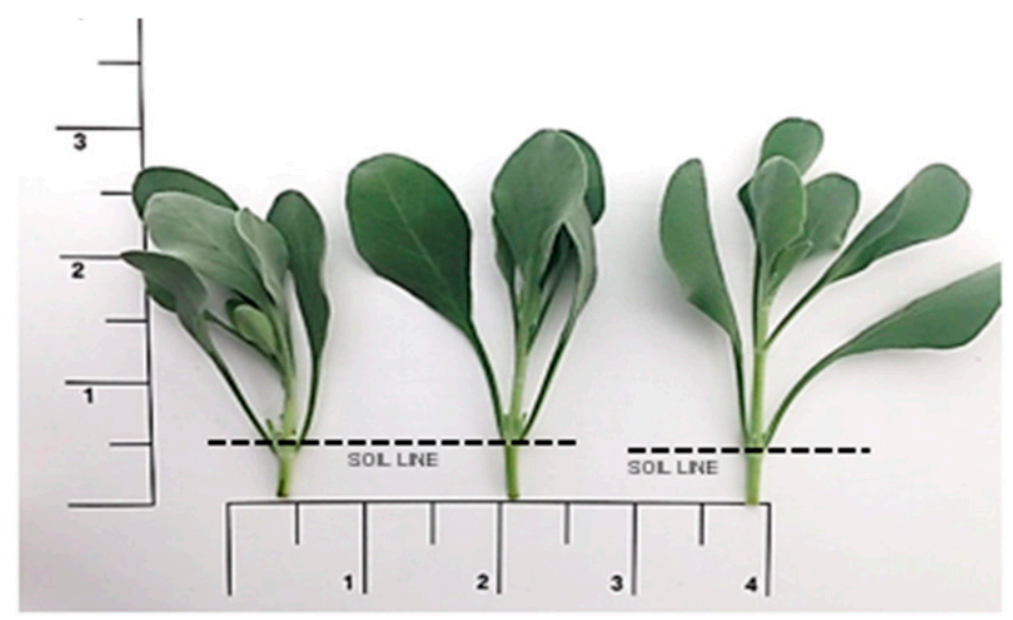

Fig. 1. Visual guide used for standardizing cuttings from mojave sage stock plants provided by Gulley Greenhouse, Fort Collins, CO. Cuttings on the right show ideal size and preparation for sticking. Measurements in inches $(1 \mathrm{inch}=2.54 \mathrm{~cm})$.
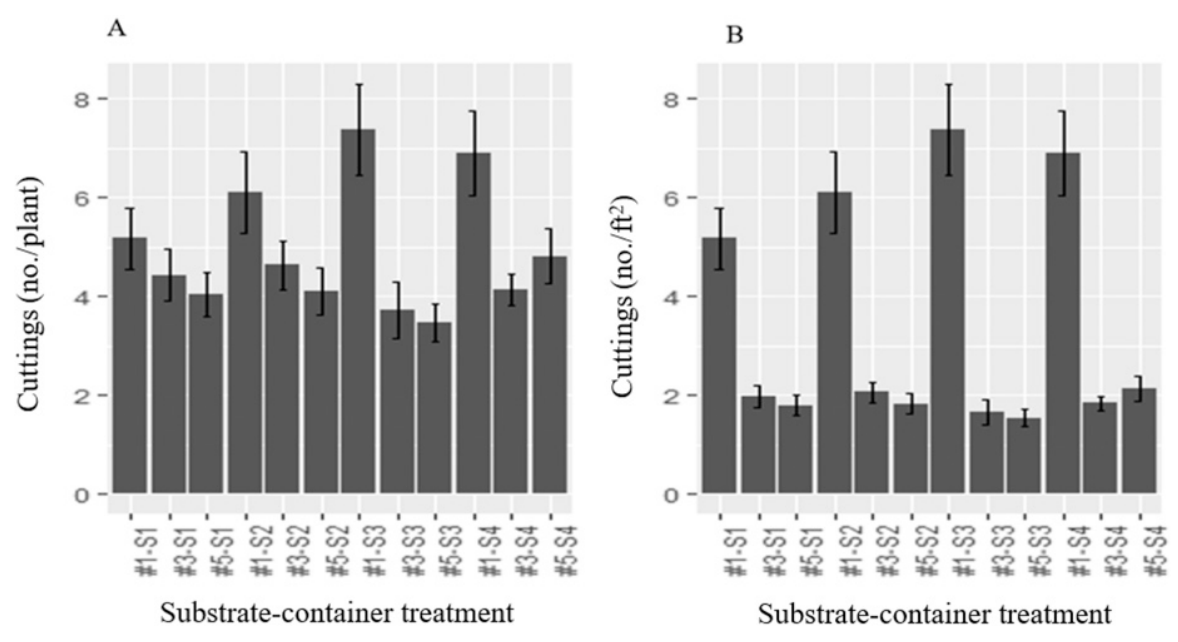

Fig. 2. Influence of substrate type and container size on mean number of cuttings harvested per plant and mean number of cuttings per square foot from mojave sage stock plants averaged over three harvest dates (Nov. 2017 to Jan. 2018) as influenced by four substrates - substrate 1 [SI (primarily bark, peat, and perlite)], substrate 2 [S2 (primarily bark, peat, and vermiculite)], substrate 3 [S3 (primarily bark, peat, and coarse perlite)], and substrate 4 [S4 (primarily peat)]-and three container sizes: \# $1,3 \mathrm{qt} ; \# 3,12 \mathrm{qt}$; and \#5, $15.5 \mathrm{qt}$. $1 \mathrm{qt}=0.9464 \mathrm{~L}, 1 \mathrm{cutting} / \mathrm{ft}^{2}=$ 10.7639 cuttings $/ \mathrm{m}^{2}$. 
Table 2. Mean fresh weight of cuttings harvested from greenhouse-grown mojave sage stock plants averaged over three harvest dates (Nov. 2017 to Jan. 2018) as influenced by four substrates: substrate 1 [SI (primarily bark, peat, and perlite)], substrate 2 [S2 (primarily bark, peat, and vermiculite)], substrate 3 [S3 (primarily bark, peat, and coarse perlite)], and substrate 4 [S4 (primarily peat)] and three container sizes. Means for substrates averaged within each container size.

\begin{tabular}{lcc}
\hline Container size $^{\mathrm{z}}$ & Substrate & Fresh wt [mean (95\% CI) ] \\
\hline \multirow{4}{*}{$\# 1$} & S1 & $1.04(0.78-1.3) \mathrm{a}^{\mathrm{x}}$ \\
& S2 & $1.17(0.91-1.43) \mathrm{a}$ \\
\#3 & S3 & $1.07(0.82-1.32) \mathrm{a}$ \\
& S4 & $1.04(0.78-1.3) \mathrm{a}$ \\
& S1 & $2.49(2.23-2.76) \mathrm{b}$ \\
& S2 & $2.5(2.25-2.76) \mathrm{b}$ \\
\#5 & S3 & $2.7(2.46-2.96) \mathrm{b}$ \\
& S4 & $2.41(2.15-2.67) \mathrm{b}$ \\
& S1 & $2.47(2.19-2.74) \mathrm{b}$ \\
& S2 & $2.48(2.23-2.73) \mathrm{b}$ \\
& S3 & $2.52(2.26-2.77) \mathrm{b}$ \\
& S4 & $2.38(2.12-2.65) \mathrm{b}$ \\
\hline
\end{tabular}

${ }^{\mathrm{z}} \# 1=3 \mathrm{qt}, \# 3=12 \mathrm{qt}, \# 5=15.5 \mathrm{qt} ; \mathrm{l}$ qt $=0.9464 \mathrm{~L}$.

${ }^{\mathrm{y}}$ Means followed by $95 \%$ confidence interval (CI).

${ }^{x}$ Mean separation in columns with Tukey adjusted least squares means at $P \leq 0.05$ (lowercase letters). Two-way analysis of variance showed a significant difference among treatments.

and $2.7 \mathrm{~g} /$ cutting, with low variability, even small differences can be important when it comes to cutting quality. Cutting weights differed based on container size, but not based on substrate or size $\times$ substrate interaction. Therefore, only data related to container size effects are presented. When averaging over substrate, the greatest fresh weight per cutting was from stock plants grown in \#3 and \#5 containers (Table 2 ).

Mojave sage stock plants grown in \#1 containers produced cuttings with the lowest mean fresh weight, with an average of $1.08 \mathrm{~g}$. These results suggest growing in a larger container could be beneficial to the mean fresh weight of cuttings and could improve cutting quality. In previous research, fresh weight of coral bells cuttings did not differ based on container size (Brown and Klett, 2020). The overall growth habit, especially root growth, of mojave sage differs from coral bells and did not become root bound in \#l containers. This could be responsible for the difference in \# 1 containers not being significant for cutting fresh weight.
Percent of rooted cuttings AND AVERAgE NUMBER OF VISIBLE ROOTs. In terms of percentage of rooted cuttings, there was no association between treatment and rooting status after 4 weeks on the mist bench. Percentage of rooted cuttings ranged from $88 \%$ to $100 \%$ rooting regardless of treatment. Also, no differences were found in the average number of visible roots after 4 weeks, container size, substrate, or interaction of size $\times$ substrate. These results indicate plant growth regulator use in stock plants does not affect successful rooting of mojave sage cuttings.

\section{Conclusions}

Mojave sage stock plants would likely perform best in a well-drained substrate, and in this experiment all the tested substrates performed equally well. For the initial 3 months after starting a new stock plant from a cutting, it is more efficient to grow them in \#l containers, as the larger containers do not provide enough advantage to justify the additional space needed. Rooting success rates were greater than $88 \%$ for all treatment combinations; therefore, we can confidently recommend using our cutting and propagation protocol for the rooting of mojave sage cuttings.

\section{Literature cited}

Adam, S.A., Jr. 2005. Nutrition and management of perennial stock plants. Comb. Proc. Intl. Plant Prop. Soc. 55:348-355.

Bouzo, C.A. and J.C. Favaro. 2015. Container size effect on the plant production and precocity in tomato (Solanum lycopersicum L.). Bulg. J. Agr. Sci. $21: 325-332$.

Brown, S.G. and J.E. Klett. 2020. Impacts of growth substrate and container size on cutting production from 'Snow Angel' coral bells stock plants. HortTechnology 30:185-192.

Fox, J. and S. Weisberg. 2011. An $\{\mathrm{R}\}$ companion to applied regression. 2 nd ed. SAGE Publishing, Thousand Oaks, CA.

Ingram, D.L., R.W. Henley, and T.H. Yaeger. 1993. Growth media for container grown ornamental plants. Univ. Florida Coop Ext Serv. Bul. 241.

Nishizawa, T. and K. Saito. 1998. Effects of rooting volume restriction on the growth and carbohydrate concentration in tomato plants. J. Amer. Soc. Hort. Sci. 123:581-585.

NeSmith,D.S. and J.R. Duval. 1998. The effect of container size. HortTechnology $8: 495-498$.

Poorter, H., F. Fiorani, M. Stitt, U. Schurr, A. Finck, Y. Gibon, B. Usadel, R. Munns, O.K. Atkin, F. Tardieu, and T.L. Pons. 2012. The art of growing plants for experimental purposes: A practical guide for the plant biologist. Funct. Plant Biol. 39:821-838.

Tonutti, P. and C. Giulivo. 1990. Effect of available soil volume on growth of young kiwi plants. Acta Hort. 282:283290.

van Iersel, M. 1997. Root restriction effects on growth and development of salvia (Salvia splendens). HortScience 32:11861190.

Xie, Z., X. Guo, and H. Cao. 2013. Effect of root restriction on vegetative growth and leaf anatomy of 'Kyoho' grapevines cultivar. Afr. J. Agr. Res. 8:1304-1309. 